publications of Congressional Quarterly, Inc., as well as the St. Petersburg Times and Evening Independent. Andrew Barnes serves as President of the Poynter Fund and Chairman of the Board and Chief Executive Officer of Times Publishing Company.

\section{Corrections Noted for Biographical Directory}

The following corrections should be made for the 1988 APSA Biographical Directory.

Dexter, Lewis A. Birthdate: $1 / / \$ 3 / 15$. Current office address: Department of Political Science, University of North Carolina at Charlotte, Charlotte, NC
28223.

Garfinkel, Herbert. Springdale Drive should read as Springvale Drive in his home address.

Hanson, Elizabeth C. Incorrectly alphabetized under Elizabeth Crump. Please see Elizabeth Crump for biographical listing.

Schlesinger, Thomas 0 . Birthdate of $6 / 11 / 28$ should read as 6/1//25.

Sontag, Frederick H. Zip code of 07073 should read as 07079 .

Woodard, Maurice $C$. His business address should read as: Staff Associate, American Political Science Association, 1527 New Hampshire Avenue NW, Washington, DC 20036. 